J. Reprod. Fert. (1970) 23, 383-391

\title{
PATTERNS OF DISTRIBUTION AND URINARY EXCRETION OF MALE RAT ACCESSORY SEX GLAND-SPECIFIC ANTIGENS
}

\author{
E. ROSENMANN, T. DISHON, A. DURST AND J. H. BOSS \\ Departments of Pathology and Surgery, Hadassah Medical School, and \\ Department of Immunology and Virology, School of Dental Medicine, \\ Hebrew University, Ferusalem, Israel
}

(Received 24th November 1969, revised 14th April 1970)

\begin{abstract}
Summary. Patterns of distribution of organ-specific antigens in the accessory sex glands of the male rat and the urinary excretion of these antigens were investigated by the immunodiffusion and immunofluorescence microscopical techniques. One organ-specific antigen was detected in the bulbo-urethral gland, two antigens were found in the prostatic gland and three common ones in the ampullary gland, seminal vesicle and coagulating gland. The antigens were localized immunohistologically in the epithelial cytoplasm and luminal excretory products of the glands. The antigens of the accessory glands were demonstrated in the urine, the only exception being the antigen of the bulbo-urethral gland. There were irregular variations in the urinary excretion of the antigens of the individual glands. The prostatic constituents were found to be the main contributors of the accessory glands to the urinary protein pool.
\end{abstract}

\section{INTRODUCTION}

The nature of the proteins excreted in the urine of the healthy rat has attracted wide attention (Addis, 1932; Bell, 1933; Sellers, Goodman, Marmorston \& Smith, 1950; Sellers, 1956). The urinary proteins are partly derived from the blood plasma and partly from other sources. Among the latter, sex-dependent proteins, possibly of renal and/or hepatic origin, have been described (Sellers et al., 1950; Roy \& Neuhaus, 1967). Normal tissue constituents of the accessory sex glands also contribute to the urinary protein pool in the male rat (Perry, 1965; Rosenmann, Dishon \& Boss, 1969; Durst, Dishon, Rosenmann \& Boss, 1969). The appearance of these tissue components in the urine is dependent upon the balance of the sex hormones (Dishon, Rosenmann, Durst \& Boss, 1970).

The present investigation was designed to elucidate the distribution of organspecific antigens within the accessory glands of the male rat as well as the pattern of excretion of these antigens in the urine. 


\section{Animals}

\section{MATERIALS AND METHODS}

Male, white, Hebrew University strain rats, weighing 200 to $400 \mathrm{~g}$, were used as experimental animals. Antisera were raised in randomly bred, local rabbits, weighing 2 to $3 \mathrm{~kg}$.

\section{Antigenic preparations}

These were obtained from pooled accessory sex glands and from individual organs.

1. Antigenic fractions of the combined seminal vesicles, ampullary glands, coagulating, prostatic and bulbo-urethral glands (hereafter referred to as accessory sex glands, ASG) were prepared as previously described in detail (Rosenmann et al., 1969). Briefly, the glands were homogenized and the product was sonically disintegrated and centrifuged at $2000 \mathrm{rev} / \mathrm{min}$ to obtain the ASG-sediment, ASG-lipid and ASG-soluble fractions. The preparations were freeze-dried and stored at $-20^{\circ} \mathrm{C}$.

2. Individual accessory sex glands were collected. The bulbo-urethral glands were removed and, following exposure of the pelvic organs, the coagulating glands were carefully separated from the seminal vesicles by blunt forceps. The prostatic lobes and ampullary glands were thereafter excised, though histological examination revealed that it was practically impossible to separate the ampullary glands completely from the neighbouring organs in every case. The pools of the five glands were individually homogenized, three times for 2 min each, in a Waring Blendor in pre-chilled distilled water. The homogenates were dialysed in the cold against distilled water, freeze-dried and kept at $-20^{\circ} \mathrm{C}$.

\section{Preparation of antisera}

Three rabbits were used to prepare each antiserum. The animals were immunized by intramuscular injections of the freeze-dried homogenates. The injections consisted of $30 \mathrm{mg}$ ASG sediment, ASG-lipid fraction, ASG-soluble fraction, ampullary glands or bulbo-urethral glands and $100 \mathrm{mg}$ seminal vesicles, coagulating or prostatic glands suspended in $2 \mathrm{ml}$ saline. The first three injections, at weekly intervals, contained aliquots of Freund's complete adjuvant. Two further injections without adjuvant were given during the 5th and 6th weeks. Blood was collected by cardiac puncture 10 days after the last administration.

\section{Absorption of antisera}

Anaesthetized rats were exsanguinated. The hearts, lungs, spleens, livers and kidneys were combined and homogenized. The blood and tissue-organ homogenates were freeze-dried. Aliquots $(20 \mathrm{ml})$ of each antiserum were incubated with $500 \mathrm{mg}$ of the freeze-dried blood and homogenate of the tissue-organs to remove antibodies reacting with blood constituents and antigens which are widespread in the organism. Following centrifugation, the supernatant fluids were tested for the presence of antibodies to blood and tissue-organ antigens by Ouchterlony's double agar gel diffusion technique. The procedure was repeated 
until no precipitation bands developed with the blood and tissue-organ homogenate.

\section{Testing of antisera for organ-specificity}

For final testing of the antisera, $100 \mathrm{mg}$ of each of the eight antigenic preparations were suspended in $10 \mathrm{ml}$ of buffered physiological saline, $\mathrm{pH} \mathrm{7.2,} \mathrm{and}$ disintegrated by ultrasonic oscillation in an Ultra-Turreax apparatus, three times for $2 \mathrm{~min}$ each, at $170 \mathrm{~V}, 75 \mathrm{~W}$ and $0.7 \mathrm{~A}$. The antisera were tested with each of these preparations by Ouchterlony's technique.

\section{Immunofluorescence microscopy}

Samples of the accessory sex glands, liver and kidney were quick-frozen and cut in a cryostat at $6 \mu$. The sections were incubated with each of the five antisera to the accessory sex glands and with normal rabbit serum for $30 \mathrm{~min}$ in a moist chamber at room temperature, washed in cold buffered saline and stained with fluorescein isothiocyanate (FITC) conjugated with goat antirabbit $\gamma$-globulin serum. The large Zeiss fluorescence outfit with an Osram high-pressure mercury lamp HBO 200 and a BG 12 excitation filter was utilized.

\section{Examination of urine specimens}

Rats were placed in metabolism cages over urine-faeces separators and urine was collected under a layer of liquid paraffin. Food was withheld but the animals had free access to water. The urine samples were tested by the immunodiffusion technique with each of the eight antisera. A urine specimen which gave one or more precipitation bands with any of the diverse anti-ASG sera was allotted a positive score (Dishon et al., 1970).

Surgical removal of accessory sex glands

Laparotomy was performed under ether anaesthesia. In one group of rats, the prostatic lobes were removed and in a second group, the seminal vesicles and coagulating glands were excised. Urine samples were collected from the 5th post-operative day and examined as described above.

\section{RESULTS}

\section{Occurrence of ASG-specific antigens in the accessory sex glands}

The absorbed antisera against the three ASG fractions and the five individual accessory sex glands did not contain precipitating antibodies reacting with blood or tissue-organ components. The precipitation patterns of the ASG fractions with the respective antisera were previously described (Rosenmann et al., 1969). The anti-ASG-sediment and anti-ASG-soluble fraction sera gave three to four precipitation bands and the anti-ASG-lipid fraction serum gave two when allowed to react with the ASG fractions. The findings indicated contamination of the preparations by fraction-foreign material, as commonly occurs when centrifugation is employed for the preparation of antigenic fractions (Mutolo \& D'Amelio, 1962; Boss, 1965). 
The reactions of the ASG-specific antisera to the individual glands with the homologous and heterologous antigenic preparations are summarized in Table 1. The anti-prostate serum produced two bands with prostate and one with the ampullary gland in a reaction of identity. The latter was probably due to minute fragments of prostatic tissue included in the preparation of the ampullary gland. Two or three precipitation bands developed, in an identity reaction, with antigens of the seminal vesicle, the ampullary gland and the coagulating gland when allowed to react with the anti-seminal vesicle serum; spur formation occurred with the latter two preparations. The anti-coagulating

TABLE 1

RESULTS OF IMMUNODIFFUSION TESTS OF ASG-SPECIFIC ANTISERA WITH ANTIGENIG PREPARATIONS OF HOMOLOGOUS AND HETEROLOGOUS AGGESSORY SEX GLANDS

\begin{tabular}{l|c|c|c|c|c}
\hline & \multicolumn{5}{|c}{ Antigenic preparation of: } \\
\cline { 2 - 6 } \multicolumn{1}{c|}{ Antiserum against: } & Prostate & $\begin{array}{c}\text { Seminal } \\
\text { vesicle }\end{array}$ & $\begin{array}{c}\text { Coagulating } \\
\text { gland }\end{array}$ & $\begin{array}{c}\text { Ampullary } \\
\text { gland }\end{array}$ & $\begin{array}{c}\text { Bulbo-urethral } \\
\text { gland }\end{array}$ \\
\hline Prostate & 2 & None & None & 1 & None \\
Seminal vesicle & None & 2 to 3 & 2 to 3 & 2 to 3 & None \\
Coagulating gland & None & 1 & 2 to 3 & 2 & None \\
Ampulary gland & None & 1 to 2 & 1 to 2 & 1 to 2 & $\begin{array}{c}\text { None } \\
\text { Bulbo-urethral gland }\end{array}$ \\
& None & None & None & None & 1 \\
\hline
\end{tabular}

The results are expressed as the number of precipitation bands developing between the diverse antisera and antigenic preparations.

TABLE 2

RESULTS OF IMMUNODIFFUSION TESTS OF ANTI-ASG-FRAGTION SERA WITH ANTIGENIG PREPARATIONS OF THE ACGESSORY SEX GLANDS

\begin{tabular}{l|c|c|c}
\hline & \multicolumn{3}{|c}{ Antiserum against: } \\
\cline { 2 - 4 } Antigenic preparation of: & $\begin{array}{c}\text { Anti-ASG-sediment } \\
\text { serum }\end{array}$ & $\begin{array}{c}\text { Anti-ASG-lipid } \\
\text { fraction serum }\end{array}$ & $\begin{array}{c}\text { Anti-ASG-soluble } \\
\text { fraction serum }\end{array}$ \\
\hline Prostate & None & 1 & None \\
Seminal vesicle & 2 & 2 & 1 \\
Coagulating gland & 1 & 2 & 2 \\
Ampullary gland & 1 & 2 & None \\
Bulbo-urethral gland & None & 1 & \\
\hline
\end{tabular}

The results are expressed as the number of precipitation bands developing between the anti-ASG fraction sera and the diverse antigenic preparations.

gland serum gave two to three precipitation bands with the coagulating gland, two with the ampullary gland and one with the seminal vesicle (Pl. 1, Fig. 1). The antiserum against the ampullary gland produced one to two precipitation lines with the ampullary gland, the coagulating gland and the seminal vesicle; spur formation occurred with the latter (Pl. 1, Fig. 2). The antiserum to the bulbo-urethral gland gave a single precipitin line with the homologous gland and none with the other four glands (Pl. 2, Fig. 4).

The reactions of the three anti-ASG fraction sera with the antigenic preparations of the five accessory sex glands are presented in Table 2. Antigens of the 


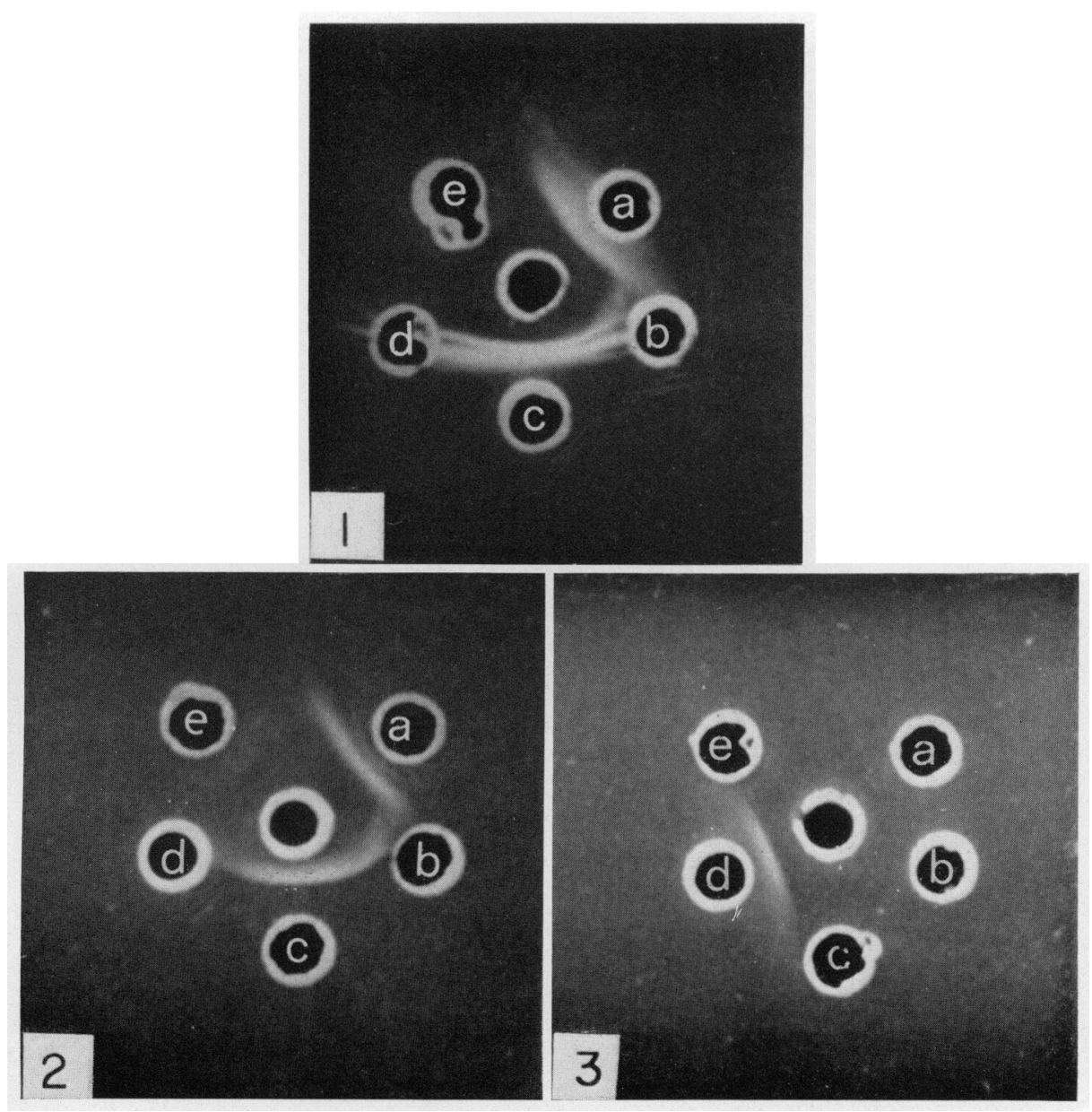

Patterns of immunodiffusion tests of anti-coagulating gland scrum (Fig. 1) and antiserum to the ampullary gland (Fig. 2) with the antigenic preparations of the ampullary gland (a), seminal vesicle (b), coagulating gland (c), bulbo-urethral gland (d) and prostate (e). Compare the cross-reactions obtained with these two antisera to the organ specificity exhibited by the anti-bulbo-urethral gland scrum (Fig. 3). 


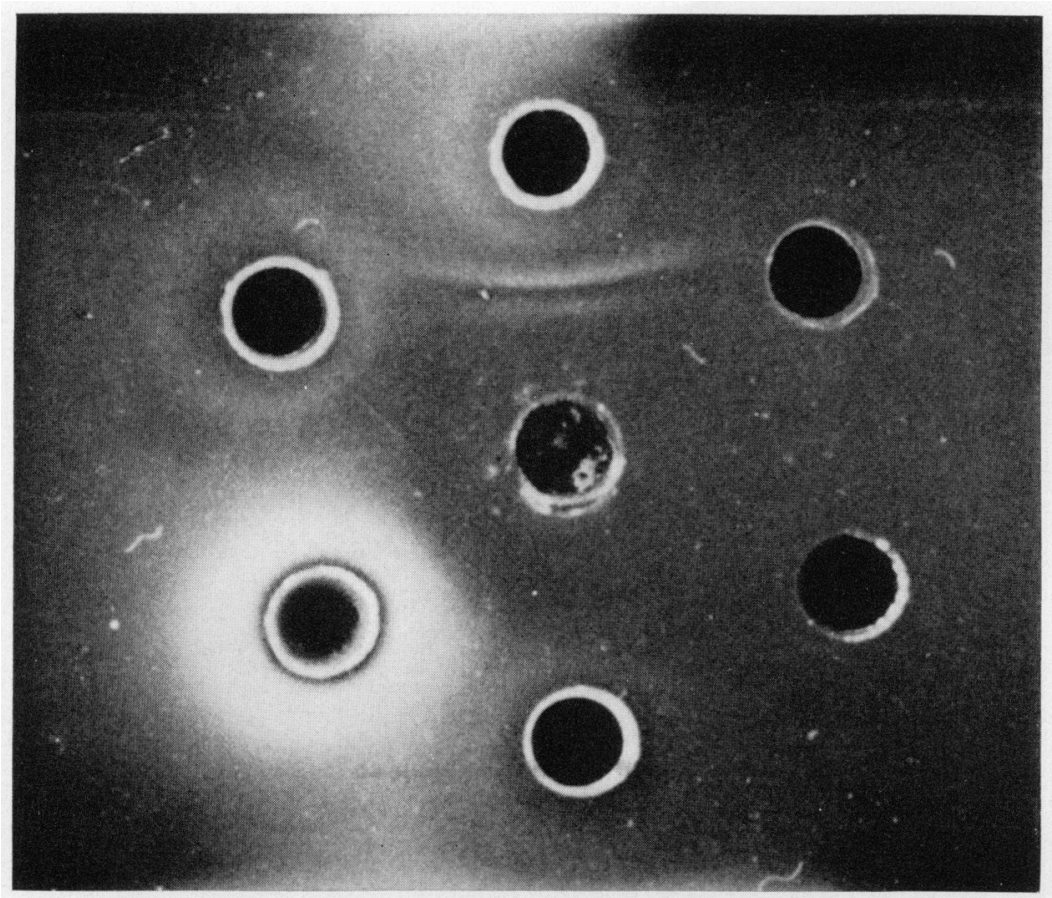

lite. 4. Lrine sample of normal male rat (centre well reacting with anti-prostate serum upper well) to elicit wo bands of precipitation. The peripherd wells contain (clockwise) antisera against the prostate, seminal vesicle, bulbo-urethral gland, ampulary gland and coagulating gland; the sixth well contains normal rabbit serum. 

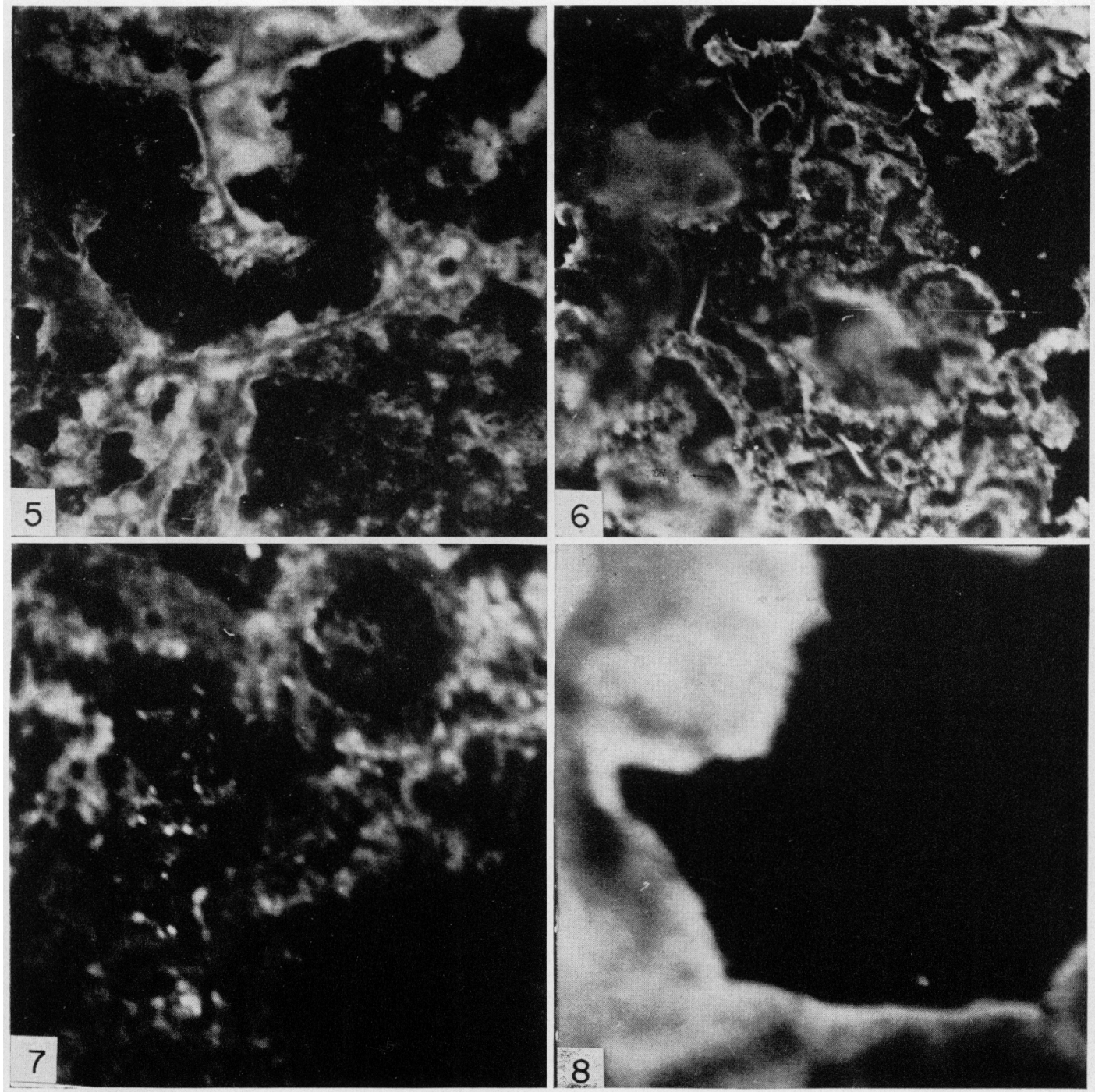

Immunofluorescence microscopical microphotographs of sections of accessory sex glands incubated with their respective rabbit antisera followed by FIC:-labelled anti-rabbit $\because$-globulin serum. Note specifie fluorescence of the epithelial cytoplasm of the seminal vesicle (Fig. 3; coagulating gland (Fig. 6) and prostate (Fig. 7). The specifically fluorescent cytoplasmic pattern of the epithelial cells of the coagulating gland is shown at highes magnification Fig. 8: 
prostatic and bulbo-urethral glands reacted only with the anti-ASG-lipid fraction serum, whereas those of the ampullary gland, the seminal vesicle and the coagulating gland reacted with all three anti-ASG-fraction sera.

\section{Localization of ASG-specific antigens by immunofluorescence microscopy}

Cryostat sections of the five accessory sex glands, kidney and liver treated with normal rabbit serum followed by incubation with FITC conjugated with goat anti-rabbit $\gamma$-globulin serum exhibited autofluorescence and a faint greyish-green, non-specific staining. Kidney and liver sections incubated with any of the five antisera against the accessory sex glands and FITC-labelled antiserum were negative. With the exception of the seminal vesicle, the accessory sex glands stained specifically with their homologous antiserum only. Bright apple-green specific fluorescence of the epithelial cytoplasm and luminal secretory product was found in the seminal vesicle when allowed to react with the antisera to seminal vesicle (Pl. 3, Fig. 5) as well as to coagulating gland. It was observed that the apical portion of the epithelial cells was strongly stained, whereas the basal part showed a weak specific fluorescence. The epithelial cytoplasm and luminal contents of the coagulating gland were positively stained with the homologous antiserum (Pl. 3, Figs. 6 and 8) but not with the antiserum to the seminal vesicle. In sections of the prostatic gland treated with anti-prostate serum, the basal portion of the epithelial cells exhibited strong, and the apical area weak, specific fluorescence (PI. 3, Fig. 7). The glandular lumina contained many bright green floccules on a greyish background. Sections of the ampullary gland, incubated with the homologous antiserum and FITG-labelled antiserum, showed that the apical part of the epithelial cells stained much more strongly than the basal area and specifically fluorescing floccules were present in the lumina. The bulbo-urethral gland, when treated with the respective antiserum, revealed irregular specific staining, some acini appearing negative and others showing a strongly granular fluorescent pattern.

\section{Urinary excretion of ASG-specific antigens in normal rats}

The anti-ASG-soluble fraction serum did not precipitate with components of male rat urine (Rosenmann et al., 1969). In ninety-five out of 127 examinations, the anti-ASG-sediment and anti-ASG-lipid fraction sera reacted concomitantly with the urine, eliciting one or two precipitation lines. Urine specimens of twelve rats were collected every 3 to 4 days for 5 weeks and examined for the presence of ASG antigens. Individual variations were conspicuous in as much as all nine samples of one animal were positive while in the remaining rats, one, two, three or four specimens were negative. A constant pattern in regard to the presence or absence of ASG components in the urine was not apparent, since consecutive samples were positive, negative or alternatingly positive and negative.

Urine samples did not react with anti-bulbo-urethral gland serum. One or two precipitation bands developed between wells containing urine and antiprostate serum (Pl. 2, Fig. 4) and one precipitin line was obtained with the other three anti-ASG sera. Out of 110 randomly collected urine samples, eighty-four reacted with anti-prostate serum, twenty-three with anti-coagulating 
gland serum, fifteen with the antiserum against the ampullary gland and eleven with anti-seminal vesicle serum. Daily variations in the excretion of the diverse glandular antigens in the urine of individual rats were marked. In some animals, all urine samples were positive with the anti-prostate serum while in others, up to half of the specimens were negative. Considerable variability was also noted when these same urines were tested with the other three antisera, all the specimens of some rats being negative, while those of other animals were occasionally or often positive.

\section{Urinary excretion of ASG-specific antigens in the absence of certain accessory glands}

The coagulating glands and seminal vesicles of five rats were surgically removed. Twenty urine samples from each animal were examined and found to be negative when allowed to react with anti-coagulating gland and antiseminal vesicle sera. On the other hand, the same specimens reacted positively with anti-prostate serum at a similar incidence to that noted in normal rats. Prostatectomy was performed in fifteen animals and the urine was examined for 1 month. The anti-seminal vesicle serum gave positive reactions in two rats only, while the anti-prostate and anti-coagulating gland sera yielded negative results. Following prostatectomy, the urine was negative with anti-ASG-lipid fraction and anti-ASG-sediment sera, while the urine of animals, the seminal vesicles and coagulating glands of which had been removed, reacted positively with these two antisera.

\section{DISGUSSION}

The presence of several organ-specific antigens in the accessory sex glands of the male rat has been demonstrated. The seminal vesicle and coagulating gland contained three ASG-specific common antigens and there was one specific antigenic tissue component in the bulbo-urethral gland while two components were present in the prostate. The cross reaction of the anti-prostate serum with the ampullary gland is explained by the technical difficulties encountered in attempting to isolate the ampullary gland (Dishon et al., 1970) and means that the results obtained with the respective antisera should be evaluated with some reserve. The fact that antibodies reacting with prostatic antigens were not present in the antiserum to the ampullary gland may have been related to the minute amounts of prostatic tissue in the antigenic preparation, which were not enough to elicit a detectable immune response in the rabbit.

The anti-ASG-lipid fraction serum reacted with all five accessory sex glands, whereas the anti-ASG-sediment and anti-ASG-soluble fraction sera failed to produce precipitation with antigens of the prostatic and bulbo-urethral glands. It was probable, therefore, that the lipoprotein moiety of the last two glands carried the antigenic organ specificity. Even though the ASG fractions are contaminated with fraction-foreign material (Rosenmann et al., 1969), their corresponding antisera can still be adequately used for the detection of specific tissue antigens (Mutolo \& D'Amelio, 1962; Boss, 1965).

Immunofluorescence microscopical examination demonstrated a seemingly higher specificity of the individual antisera than would have been expected from 
the results of the immunodiffusion tests. With the exception of the seminal vesicle, which specifically binds both anti-seminal vesicle and anti-coagulating gland antibodies, the other accessory glands were specifically stained by the indirect Coons' technique only when treated with their respective antisera. The discrepancy between the results of the two techniques was probably due to the lower sensitivity of immunofluorescence microscopy, thus bringing about an apparent augmentation of specificity. In summary, the findings obtained by immunodiffusion and immunofluorescence microscopy showed that one specific antigen was present in the bulbo-urethral gland and two in the prostate and that three antigens were shared by the seminal vesicle and coagulating gland. The antigenic composition of the ampullary gland cannot be determined with certainty by our methods, though ASG-specific components undoubtedly exist in this organ too.

Tissue constituents of the accessory sex glands, of one kind or another, are excreted in the urine of healthy rats, with the exception of those of the bulbourethral gland. The prostatic antigens are most commonly detected in the urine and are followed by the antigens of the coagulating gland, ampulluary gland and seminal vesicle in decreasing order of frequency. Considering that all five glands have direct anatomical connections with the urethra, no ready explanation can yet be offered as to the disparity in the incidence of appearance of ASG antigens in the urine. Examination of urine samples collected on different days from one and the same rat revealed conspicuous variations in the pattern of excretion of ASG antigens. These variations were possibly a function of the activity of the hypothalamo-pituitary axis, since urinary excretion of ASG constituents is known to be dependent on the balance of the sex hormones (Dishon et al., 1970).

In the pertinent literature, references are generally made to human and other mammalian antigens of either the prostate, prostatic fluid or seminal plasma (Barnes, Soanes, Mamrod, Gonder \& Shulman, 1963; Barnes, Shulman, Gonder \& Soanes, 1965; Shulman, Yantorno, Barnes, Gonder, Soanes \& Witebsky, 1965; Yantorno, Shulman, Gonder, Soanes \& Witebsky, 1966; Ablin, Soanes \& Gonder, 1969; Hekman \& Ruemke, 1969; Quinlivan, 1969). Shulman, Yantorno, Soanes, Gonder \& Witebsky (1966), studying the seminal vesicle, coagulating, bulbo-urethral and prostatic glands of the rabbit in an isologous system, have demonstrated two common species- and organ-specific antigens. The contrasting results of their work and ours may be explained by the different immunization technique; we have succeeded in detecting antigens which are specific to the individual glands. According to Barnes et al. (1963), human prostatic fluid contains four to five specific antigens. Their immunofluorescence microscopical observations are similar to ours, the cells lining the prostatic acini and the luminal secretory products being positively stained. Flocks, Bandhaur, Patel \& Begley (1962) described two prostate-specific antigens in man. A seminal vesicle-specific antigen, assumed to be coating the spermatozoa, was found by Weil \& Rodenburg (1962). Homologous antiserum produced by multiple freezing in situ of the urogenital tissues in the rabbit can be shown by Coons' technique to localize in the acinar epithelial cells and luminal material of the coagulating gland (Ablin, Gonder \& Soanes, 1969).

While the antigenic make-up of the accessory sex glands has been extensively 
investigated, the urinary excretion of ASG tissue components has attracted only cursory attention. Whether or not proteins of the accessory glands contribute to proteinuria in the healthy male animal and man has been discussed ever since the appearance of the original publication by Addis (1932). Bell (1933) was of the opinion that tissue constituents of the accessory glands were excreted in the urine, while Sellers (1956) emphatically denied the possibility of contamination of the urine by components of the lower genito-urinary tract. Grant (1959) demonstrated 'seminal proteins from the genital tract' in human urine, that were believed to originate from the bulbo-urethral and prostatic glands. Perry (1965) found a protein presumed to be of prostatic origin in an electrophoretic examination of the urine of rats.

In the present investigation, it has been established that, with the exception of the bulbo-urethral gland, the other accessory sex glands all contribute to the urinary protein pool in the male rat. The urinary excretion of ASG constituents is subject to irregular variation. Various combinations in the urinary excretion of these antigens are demonstrable. The most commonly encountered ASG constituents participating in proteinuria are of prostatic origin. Evidence supporting this observation was obtained from urine examinations of rats from which the accessory sex glands had been excised. Following the removal of the seminal vesicle and coagulating gland, ASG antigens were detected in the urine by anti-ASG-sediment and anti-ASG-lipid fraction sera, but in prostatectomized rats the urine was, with a rare exception, negative as judged by the reactions with these two antisera.

\section{ACKNOWLEDGMENTS}

This investigation was supported in part by the R. Kunin and S. Lunenfeld Fund.

\section{REFERENCES}

Ablin, R. J., Gonder, M. J. \& Sonnes, W. A. (1969) Fluorescent studies of antibodies to rabbit male urogenital tissue. Experientia, 25, 993.

Ablin, R. J., Soanes, W. A. \& Gonder, M. J. (1969) Immunologic studies of the prostate. A review. 7. int. Coll. Surg. 52, 8.

Addrs, T. (1932) Proteinuria and cylindruria. Proc. Calif. Acad. Med. 2, 38.

Barnes, G. W., Shulman, S., Gonder, M. J. \& Soanes, W. A. (1965) Further studies of the immunological properties of human prostatic fluid. 7. Lab. clin. Med. 66, 741.

Barnes, G. W., Soanes, W. A., Mamrod, L., Gonder, M. J. \& Shulman, S. (1963) Immunologic properties of human prostatic fluid. F. Lab. clin. Med. 61, 578.

BELL, M. E. (1933) Albuminuria in normal male rat. F. Physiol., Lond. 79, 191.

Boss, J. H. (1965) Antigenic relationships between the placenta and kidney in the human. Am. $\mathcal{F}$. Obstet. Gynec. 93, 574.

Dishon, T., Rosenmann, E., Durst, A. \& Boss, J. H. (1970) Proteinuria in the male rat: sex hormone dependent excretion of accessory genital glands antigens. Am. F. Physiol. $219,92$.

Durst, A., Dishon, T., Rosenmann, E. \& Boss, J. H. (1969) Proteinuria in the rat: a comparison of tissue components in the voided and renal pelvic urine. Experientia, 25, 1052.

Flocks, R. H., Bandhaur, K., Patel, G. \& Begley, B. J. (1962) Studies on spermagglutinating antibodies in antihuman prostate sera. F. Urol. 87, 475.

Grant, G. H. (1959) The proteins of normal urine. II. From the urinary tract. F. clin. Path. 12, 510.

Hekman, A. \& Ruemke, P. (1969) The antigens of human seminal plasma. With special reference to lactoferrin as a spermatozoa-coating antigen. Fert. Steril. 20, 312.

Mutolo, V. \& D'Amelo, V. (1962) Antigen-distribution in rat liver mitochondria. Experientia, 18, 556.

Perry, S. W. (1965) Proteinuria in the Wistar rat. F. Path. Bact. 89, 729. 
Quinlivan, W. L. G. (1969) The specific antigens of human seminal plasma. Fert. Steril. $20,58$.

Rosenmann, E., Dishon, T. \& Boss, J. H. (1969) Excretion of accessory genital glands-specific antigens in the urine of healthy male rats. F. Lab. clin. Med. 74, 31.

Roy, A. K. \& Neuhaus, O. W. (1967) Androgenic control of a sex-dependent protein in the rat. Nature, Lond. 214, 618.

Sellers, A. L. (1956) The mechanism and significance of protein excretion by the normal kidney. Arch. intern. Med. 98, 801.

Sellers, A. L., Goodman, H. G., Marmorston, J. \& Smith, M. (1950) Sex difference in proteinuria in the rat. Am. J. Physiol. $163,662$.

Shulman, S., Yantorno, C., Barnes, G. W., Gonder, M. J., Soanes, W. A. \& Witebsky, E. (1965) Studies on autosensitization to prostatic tissue and related tissue. Ann. N.Y. Acad. Sci. 124, 279.

Shulman, S., Yantorno, C., Soanes, W. A., Gonder, M. J. \& Wrtebsky, E. (1966) Studies on organ specificity. XVI. Urogenital tissue and auto-antibodies. Immunology, 10, 99.

Weil, A. J. \& Rodenburg, J. M. (1962) The seminal vesicle as the source of the spermatozoa-coating antigen of seminal plasma. Proc. Soc. exp. Biol. Med. 109, 567.

Yantorno, G., Shulman, S., Gonder, M. J., Soanes, W. A. \& Wrtebsky, E. (1966) Studies on organ specificity. XVIII. Immunologic and biophysical characterization of canine prostatic fluid. $\mathcal{F}$. Immunol. 96, 1035. 